\title{
Polish School Nurses' Attitudes and Knowledge towards Topical Fluoride Treatment
}

\section{Stajališta i znanja školskih medicinskih sestara o topikalnoj primjeni fluorida u Poljskoj}

\author{
${ }^{1}$ Department of Dentistry Propaedeutics, Medical University of Bialystok \\ Zavod za stomatološku propedeutiku Medicinskog sveučilišta Bialystok \\ 2 Department of Restorative Dentistry, Medical University of Bialystok \\ Zavod za restaurativnu stomatologiju Medicinskog sveučilišta Bialystok \\ ${ }^{3}$ Department of Population Medicine and Civilization Diseases Prevention, Medical University of Bialystok \\ Zavod za populacijsku medicine i preventivne bolesti Medicinskog sveučilišta Bialystok
}

\section{Abstract}

Aim: The aim of this study was to evaluate the Polish school nurses' opinion on the topical fluoride treatment and their knowledge about fluoride safety. Material and methods: A cross-sectional study with the use of a self-administered questionnaire was conducted on 164 school nurses. The questionnaire concerned previous training in caries prevention, action taken at schools with regard to caries prevention, cooperation with dentists, opinion on the topical fluoride application program and nurses' knowledge about fluoride safety. Results: $93.9 \%$ of nurses included oral health in their duties and $81.7 \%$ accomplished the topical fluoride treatment. 52.1\% never attended any training concerning dental issues. Nurses from cities and villages more often than those from towns provided lectures on caries prevention and fluoride topical applications (respectively $p=0.033$ and $p=0.021$, chi2 test). The nurses had a positive opinion on the effectiveness and safety of topical fluoride application. Only a half of respondents knew the fluoride probable toxic dose and one fifth of them did not know the concentration of fluoride in gel. The knowledge was statistically dependent on the level of nurses' education ( $p=0.019$, Kruskal-Wallis test). Nurses with a low level of knowledge were not aware of a potential harm effect of fluoride and they had negative opinion about the effectiveness of fluoride program at school. Conclusion: Polish school nurses had a positive opinion on topical fluoride treatment. However, there are gaps in their knowledge and the institutional training is needed.
Received: January 6, 2019

Accepted: May 13, 2019

Address for correspondence Joanna Baginska Medical University of Bialystok Department of Dentistry Propaedeutics

Ul. Szpitalna 30, 15-295 Bialystok Poland

jbaginska@wp.pl

Key words

School Nurses; Fluoride Topical Treatment; Knowledge

\section{Introduction}

Dental caries is the most widespread disease in the world (1). Even though a continuous decrease in caries prevalence and experience in Polish children is observed, these levels are still very high (2). This disease has a great impact on child's life, results in lowering the quality of life, and generates many economic costs $(3,4)$. As caries is a lifestyle disease, the measures to prevent cavity development should be taken from the childhood. There are three main subject areas within the scope of oral health promotion, including oral hygiene, proper nutrition and the use of fluoride compounds.

Fluoride (F) has been the most efficient caries preventive agent responsible for the decline in dental caries over the last decades (5). The mechanism of its actions is multidirectional. Fluoride reduces dental plaque formation, inhibits enolase resulting in a decrease in the level of glycolytic intermediates, affects bacterial cellular membrane permeability, inhibits demineralization and increases remineralization. If $\mathrm{F}$ is present in the biofilm environment and the $\mathrm{pH}$ is not lower than 5.5,

\section{Uvod}

Karijes je najraširenija bolest na svijetu (1). Iako je uočeno stalno smanjenje prevalencije karijesa kod djece u Poljskoj, razina je još veoma visoka (2). Bolest snažno utječe na dijete i rezultira lošijom kvalitetom života, a ima i velik ekonomski utjecaj $(3,4)$. Budući da je karijes bolest na koju utječe način života, mjere za njegovu prevenciju trebaju se provoditi od djetinjstva. Tri su glavna područja djelovanja u promidžbi oralnoga zdravlja - oralna higijena, pravilna prehrana i primjena preparata fluora.

Fluor $(F)$ je najučinkovitije sredstvo za prevenciju karijesa i zaslužan je za njegovo smanjenje u posljednjih nekoliko desetljeća (5). Mehanizam njegova djelovanja je višestruk. Fluor smanjuje stvaranje dentalnoga plaka, inhibira enolazu i razinu glikolitičkih intermedijarnih spojeva te povećava remineralizaciju. Ako se nalazi u okolini biofilma, a pH nije manji od 5,5, otapanje hidroksiapatita (HA) potiče stvaranje fluorapatita (FA). Kako se ciklusi demineralizacije i remineralizacije ponavljaju, vanjske slojeve cakline čine otpornijima na kise- 
the dissolution of hydroxyapatite (HA) promotes the Fluor apatite (FA) formation. Repeated cycles of demineralization and remineralization make the outer parts of enamel more resistant to acidic environment $(5,6)$. Fluoride can be delivered to the organism orally and topically. Using fluoride toothpaste twice a day is considered to be a basic caries-preventive strategy. Apart from daily hygiene routine, the home-used or professionally-applied high concentration topical agents should be used in high risk populations (7). The application of a high concentration of $\mathrm{F}$ ions results in the calcium fluoride-like globules formation on the tooth surface. They are mineral reservoirs releasing calcium, phosphate and fluoride after acid attacks (8). For professional application the gels, foams and varnishes with a concentration between 0.5 and $5 \%$ are recommended. Currently, the indications for fluoride prophylaxis and the frequency of application depend on the individual caries risk; fluoride applications are recommended in individuals with a moderate and high caries risk (7).

Despite its positive effect on teeth, fluoride may cause an acute and chronic toxicity. An overexposure to small doses during first years of life results in enamel development disturbances named fluorosis. People living in areas where the fluoride level in drinking water is above $1.5 \mathrm{mg} / \mathrm{l}(1.5 \mathrm{ppm})$ are exposed to fluorosis. Currently, multiple sources of fluoride exposure, e.g. fluoride-containing dental products, fluoride enriched food and water are considered to be a reason for a growing number of children with fluorosis symptoms $(9,10)$. Potentially, a harmful effect may result from a daily ingestion of topical fluoride, from toothpaste or from home use gels. An acute poisoning may occur after the ingestion of one or more doses of fluoride over a short time period. First symptoms are nausea, abdominal pain, bloody vomiting and diarrhea. They are followed by headache, cardiac arrhythmia, excess salivation, collapse with paleness, weakness, wet, cold skin, shallow breathing, spasms, muscle paralysis, and tetany. The abovementioned symptoms are an effect of metabolic disorders, mainly hypocalcaemia, hyperkalemia and acidosis. Acute fluoride toxicity often results in death (11). In children, first signs of poisoning may occur after the ingestion of $1-5 \mathrm{mg} / \mathrm{kg}$ of fluorides (probable toxic dose, PTD), and the lethal dose (LD) is calculated to be between 8 and $16 \mathrm{mg} / \mathrm{kg}$ $(10,11)$. Even though the cases of acute fluoride poisoning are very rare nowadays (12), the possibility of overdose due to unsupervised ingestion of dental products still exists (11).

It has been proven that school/kindergarten-based programs for caries prevention with topical fluoride are cost-effective, with a high ratio of caries reduction (13-15). In Poland, since 2004, a fluoride program funded by the National Health System (NHS) for all children attending primary schools has been available. The procedures are performed in classes 1 to 6 , six times in a school year (every 6 weeks) with the method of supervised toothbrushing using a $1.25 \%$ gel. The prevention is provided in areas where the fluoride levels in drinking water exceed $1 \mathrm{mg} / \mathrm{l}$. Joining the program requires a written parental consent. The procedure is supervised by a school nurse or school hygienist. Therefore, school nurses play an important role in caries prevention with topical fluoride in Poland, but little is known about their opinions li okoliš $(5,6)$. Fluor se može primjenjivati oralno i topikalno. Korištenje zubne paste s fluorom dva puta na dan smatra se preventivnom karijesnom strategijom. Uz svakodnevnu higijenu, preporučuje se korištenje proizvoda s visokim udjelom fluora, bilo kod kuće, bilo u profesionalnim okvirima, i to za populaciju s visokim rizikom od karijesa (7). Primjena velike koncentracije iona fluora kao posljedicu ima stvaranje globula kalcijeva fluorida na površini zuba. To su mineralni spremnici koji otpuštaju kalcij, fosfate i fluor nakon navale kiseline (8). Za profesionalnu primjenu preporučaju se gelovi, pjene i lakovi u koncentraciji od 0,5 do $5 \%$. Trenutačno indikacije za fluoridnu profilaksu i frekvenciju primjene ovise o individualnom riziku od karijesa. Primjena fluora preporučuje se pojedincima s umjerenim i visokim rizikom od karijesa (7).

Unatoč pozitivnom djelovanju na zube, fluor može uzrokovati akutno i kronično otrovanje. Pretjerana izloženost malim dozama u prvim godinama života može poremetiti razvoj cakline koji se naziva fluorozom. Populacije koje žive u područjima $s$ visokim razinama fluora u vodi (većima od 1,5 $\mathrm{mg} / \mathrm{l}$, odnosno 1,5 ppm) mogu biti zahvaćene fluorozom. Danas se smatra da su razlozi za povećani broj djece sa simptomima fluoroze upravo u izloženosti velikom broju izvora fluora kao što su, na primjer, dentalni proizvodi s fluorom, te hrana i voda obogaćena fluorom $(9,10)$. Štetni se učinak može pojaviti i zbog svakodnevnog gutanja topikalnog fluorida, zubne paste te gelova koji se upotrebljavaju kod kuće. Akutno otrovanje može nastati nakon ingestije jedne ili više doza fluorida u kratkom razdoblju. Prvi simptomi su mučnina, abdominalna bol, krvavi vomitus te dijareja. Slijede glavobolja, srčana aritmija, pretjerana salivacija, kolaps s bljedilom, slabost, hladna koža, plitko disanje, grčevi, paraliza mišića te tetanija. Sve navedeno posljedica je metaboličkih poremećaja, uglavnom hipokalcemije, hiperkalemije i acidoze. Akutna toksičnost fluorida često može prouzročiti smrt (11). Kod djece se prvi znakovi trovanja mogu pojaviti nakon gutanja od 1 do $5 \mathrm{mg}$ fluorida na $1 \mathrm{~kg}$ tjelesne mase (vjerojatna toksična doza; engl. probable toxic dose - PTD), a letalna doza iznosi između 8 i $16 \mathrm{mg} / \mathrm{kg}(10,11)$. Iako su slučajevi akutnog trovanja fluoridima danas rijetki (12), još postoji opasnost od predoziranja zbog nekontroliranog gutanja proizvoda koji sadržavaju fluor (11).

Dokazano je da su školski i predškolski programi prevencije karijesa koji obuhvaćaju topikalnu primjenu fluorida isplativi te da znatno reduciraju karijes $(13-15)$. U Poljskoj se od 2004. godine u osnovnim školama provodi program fluoridacije, a podupire ga državni zdravstveni sustav. Postupci se provode od prvog do šestog razreda, šest puta tijekom školske godine (svakih 6 tjedana) metodom nadziranog četkanja zuba gelom s 1,25 \% fluorida. Prevencija se obavlja u područjima gdje je razina fluora u pitkoj vodi veća od $1 \mathrm{mg} / \mathrm{l}$. Uključivanje u program zahtijeva pristanak roditelja. Postupak nadzire školska medicinska sestra ili školski higijeničar. Zato u Poljskoj školske medicinske sestre imaju važnu zadaću u prevenciji karijesa na temelju topikalne primjene fluorida, no malo se zna o njihovu mišljenju o tom postupku te koliko znaju o akutnoj toksičnosti fluorida. 
about this program as well as their knowledge in this area. The purpose of this study was to evaluate school nurses' opinions on the topical fluoride treatment and their knowledge of acute fluoride toxicity.

\section{Material and methods}

A descriptive cross-sectional study with the use of a selfadministered questionnaire was conducted from January to April 2014 on randomly selected school nurses. The survey concerned several aspects of the role of school nurse in maintaining oral health in pupils, e.g. caries prevention and first aid in dental trauma. The protocol of the study was approved by the Bioethical Committee of the Medical University of Bialystok, Poland.

\section{Study population}

Three hundred and thirty-three school nurses were selected from the internet database of the Central Statistical Office of Poland. The following assumptions were made to establish the minimum sample size for the evaluation of the role of school nurses in caries prevention: the number of school nurses based on data from the Polish Ministry of Health to be about 8,000 , the percentage of nurses whose duties include the application of topical fluoride (estimated sample size) based on a pilot study to be $95 \%$, the confidence level $95 \%$, maximum error $5 \%$. The minimum sample size was estimated to be 72 nurses. All participants received a questionnaire with a pre-paid return envelope, notes on the aim of the study and a participation consent form.

\section{Questionnaire}

A structured self-administrative questionnaire was tested in a pilot study on 37 school nurses. After the pilot study, one question about the time of eruption of primary and permanent teeth was removed because it was not relevant to the study. The final questionnaire comprised questions concerning the duration of employment as school nurse, the education level, the work location type, previous training on caries prevention, actions taken at school, and cooperation with dentists. The questionnaire contained also a part concerning the topical fluoride application program; this part was completed by the nurses who accomplished the NHS program. Questions regarded the percentage of pupils having fluoride prophylaxis, their opinion about the effectiveness and safety of fluoride application and 5 questions evaluating nurse's knowledge of fluoride toxicity. The knowledge was assessed by counting points for every correct answer. Due to two questions in multiple response type, the maximum number of points was 12 .

\section{Statistical analysis}

Data were analyzed using the Statistica 12.0. The Kruskal-Wallis and Chi square tests with the level of statistical significance at $\mathrm{p}<0.05$ were used.

\section{Results}

Since 164 nurses responded to the survey, the response rate for this study was $49.25 \%$. The duration of employment

\section{Materijal i metode}

Deskriptivno presječno istraživanje $s$ pomoću anketnog upitnika trajalo je od siječnja do travnja 2014. godine, a sudjelovale su slučajno odabrane školske medicinske sestre. Bilo je uključeno nekoliko aspekata uloge školske medicinske sestre u održavanju oralnoga zdravlja učenika, tj. u prevenciji karijesa i prvoj pomoći u slučaju dentalne traume. Protokol istraživanja odobrilo je Bioetičko povjerenstvo Medicinskog fakulteta u Bialystoku, u Poljskoj.

\section{Uzorak}

Iz baze podataka Središnjega statističkog ureda odabrane su 333 medicinske sestre. Sljedeće pretpostavke odredile su minimalnu veličinu uzorka za procjenu zadaća školskih medicinskih sestara u prevenciji karijesa - broj školskih medicinskih sestara, prema podatcima Ministarstva zdravlja, iznosio je oko 8000, postotak sestara čiji posao uključuje uporabu topikalnog fluorida (procijenjena veličina uzorka) na temelju pilot-istraživanja bio je $95 \%$, interval pouzdanosti bio je određen na $95 \%$, a maksimalna pogreška iznosila je $5 \%$. Minimalni uzorak bio je procijenjen na 72 medicinske sestre. Sve ispitanice dobile su upitnik s unaprijed plaćenom poštarinom, informacije o svrsi istraživanja te formular za informirani pristanak o sudjelovanju u istraživanju.

\section{Upitnik}

U testiranju strukturiranog upitnika sudjelovalo je 37 školskih medicinskih sestara. Nakon pilot-istraživanja, iz upitnika je brisano pitanje o erupciji mliječnih i trajnih zuba jer se pokazalo nevažnim. Konačna verzija upitnika sadržavala je pitanja o stažu na radnom mjestu školske medicinske sestre, o razini izobrazbe, vrsti i lokaciji radnog mjesta, ranijoj edukaciji o prevenciji karijesa, mjerama koje se provode u školi te o suradnji s doktorima dentalne medicine. Upitnik je također sadržavao pitanja o programu topikalne primjene fluorida, no popunjavale su ga one sestre koje su provodile prevenciju. Pitanja su se odnosila na postotak učenika koji su primili profilaksu, njihovo mišljenje o učinkovitosti i sigurnosti primjene fluorida te pet pitanja kojima se procjenjivalo znanje sestara o toksičnosti fluorida. Znanje se procjenjivalo zbrajanjem bodova za svaki točan odgovor. Dva su pitanja imala više ponuđenih odgovora pa je ukupan zbroj bodova bio 12 .

\section{Statistička analiza}

Podatci su analizirani programom Statistica 12.0. Za ispitivanje razine statističke značajnosti korišteni su KruskalWallisov test $\mathrm{i}$ hi-kvadrat test na razini od $\mathrm{p}<0,05$.

\section{Rezultati}

Ukupno su 164 sestre vratile upitnik, pa je stupanj odgovora bio $49,25 \%$. Staž na radnom mjestu školske medicinske 
as school nurse varied (from 1 year to 43 years), but the majority of nurses had a long experience, with the average period of $23 \pm 9.1$. A large number of respondents had secondary education; only $39(23.8 \%)$ persons had a university degree - there were 20 nurses with a Bachelor's degree and 19 with a Master's degree. The location of nurses' working place was as follows: city over $100000-45$ (27.4\%), town up to 100000 $-70(42.7 \%)$, town up to $20000-28(17.1 \%)$ and village $14(8.5 \%)$. Six nurses did not answer the question about their education and seven missed the question about the working place.

Only $10(6.1 \%)$ nurses declared that oral health was not included in their duties and for $71(43.3 \%)$ subjects dental issues took a substantial part of their practice. They were as follows: lectures on caries prevention $(135,81.8 \%)$, topical fluoride applications $(134,81.2 \%)$, oral hygiene instructions $(124,75.1 \%)$, lectures on dental trauma prevention and screening for caries and malocclusion $(7,4.2 \%)$. A statistical analysis revealed that nurses working at schools located in big cities and villages more often than those from towns provided lectures on caries prevention and topical fluoride applications (respectively $\mathrm{p}=0.033$ and $\mathrm{p}=0.021$, chi 2 test). Almost all respondents (95.6\%) declared that pupils asked them for advice in the case of such dental problems as toothache, gum bleeding or halitosis. The statistical analysis showed that children from schools located in villages more often asked for such help than their colleagues from towns and cities ( $\mathrm{p}=$ 0.025 , chi2 test). Only 40 nurses (24.4\%) established the cooperation with a dentist. Such cooperation was most frequently declared by nurses from small towns $(31.4 \%)$ and most seldom by respondents from villages (10.9\%), however, the results were not statistically significant. More than a half of the respondents $(86,52.4 \%)$ never attended any training concerning caries prevention. There were no differences depending on nurse education and location of school.

In the evaluated group, 134 (81.7\%) nurses accomplished the NHS program for topical fluoride application in pupils. They assumed the percentage of children taking part in this program to be from $40 \%$ to $100 \%$, on average $90.25 \%$. Generally, nurses had a positive opinion on the effectiveness of fluoride application: 39 (29.1\%) of them noticed a great value of such program and $84(62.7 \%)$ considered its effects to be sufficient. Only 7 (5.2\%) subjects thought the program did not have any influence on pupils' dentition, and $4(3 \%)$ nurses did not have any opinion. They also had a positive opinion on the safety of topical fluoride application. 99 (73.9\%) respondents correctly answered that this method was safe subject to proper procedures and $(20.2 \%)$ considered it to be totally safe. There were only $6(4.4 \%)$ subjects who had any doubts about it, and $4(3 \%)$ nurses were convinced that the methods involved a great risk of overexposure to fluoride.

The evaluation of nurses' knowledge of fluoride acute toxicity revealed some gaps (Table 1). They had problems with choosing all symptoms of fluoride poisoning and proper first aid measures in acute fluoride toxicity. Only a half of the respondents knew the probable toxic dose of fluoride and almost one fifth of the respondents did not know the concentration of fluoride in gel they used. The average number of sestre varirao je od 1 do 43 godine, ali većina je imala veliko iskustvo - prosječna vrijednost bila je $23 \pm 9,1$. Većina je navela da je završila srednju školu, a samo $39(23,8 \%)$ imalo je fakultetsko obrazovanje - 20 sestara bile su prvostupnice (bakalaureatkinje), a 19 magistre. Kad je riječ o radnom mjestu, raspodjela je bila sljedeća: u gradovima s više od 100000 stanovnika radilo je $45(8,5 \%)$ sestara, u gradovima do 100000 stanovnika 70 (42,7\%), u gradovima do 20000 stanovnika $28(17,1 \%)$, a u selima 14 (8,5\%) sestara. Šest ispitanica nije odgovorilo na pitanje o edukaciji, a sedam je preskočilo pitanje o radnom mjestu.

Samo 10 sestara $(6,1 \%)$ izjavilo je da oralno zdravlje nije uključeno u njihovu obvezu, a za 71 ispitanicu (43,3\%) dentalna su pitanja bila važan dio njihova rada. Ta su pitanja uključivala predavanja o prevenciji karijesa $(135-81,8 \%)$, topikalnu primjenu fluorida $(134-81,2 \%)$, upute u oralnoj higijeni $(124-75,1 \%)$, predavanja o prevenciji traume zuba te preglede zbog anomalija $(7-4,2 \%)$. Statistička analiza pokazala je da sestre koje rade u školama u velikim gradovima i selima češće drže predavanja o prevenciji karijesa i češće primjenjuju fluoride ( $\mathrm{p}=0,033 \mathrm{i} \mathrm{p}=0,021$ - hi-kvadrat test). Gotovo sve ispitanice $(95,6 \%)$ izjavile su da su ih učenici pitali za savjet u situacijama kao što su zubobolja, krvarenje zubnog mesa ili zadah. Statistička analiza pokazala je da djeca iz seoskih škola češće traže pomoć od svojih vršnjaka u većim i manjim gradovima ( $p=0,025-$ hi-kvadrat test). Samo 40 sestara $(24,4 \%)$ suradivalo je s doktorom dentalne medicine. To se događalo uglavnom u manjim gradovima $(31,4 \%)$, a najrjeđe u selima $(10,9 \%)$, no razlike nisu bile statistički značajne. Više od pola ispitanica $(86-52,4 \%)$ nikada nije bilo na edukaciji o prevenciji karijesa. Nije bilo razlike kad je riječ o izobrazbi sestara i o lokaciji škole.

U ispitivanoj skupini 134 sestre $(81,7 \%)$ sudjelovale su u edukaciji o topikalnoj fluoridaciji djece u organizaciji državnoga zdravstvenog sustava. Pretpostavljale su da je postotak djece koja sudjeluju u tom programu između 40 i $100 \%$ - u prosjeku 90,25\%. Općenito su sestre imale pozitivno mišljenje o učinkovitosti primjene fluorida - njih $39(29,1 \%)$ istaknulo je visoku vrijednost tog programa, a $84(62,7 \%)$ smatralo je da učinci zadovoljavaju. Samo 7 ispitanica $(5,3 \%)$ istaknulo je da program ne utječe na denticiju učenika, a 4 sestre (3\%) nisu imale mišljenje. Pozitivno mišljenje imale su i o sigurnosti topikalne primjene fluorida. Da je metoda sigurna ako se provodi prema određenom protokolu, točno je odgovorilo njih $99(73,9 \%)$, a $(20,2 \%)$ smatralo je da je potpuno sigurna. Samo 6 ispitanica (4,4 \%) izrazilo je sumnju, a 4 sestre (3\%) bile su uvjerene da se djeca izlažu riziku od prevelike količine fluora.

Procjena znanja sestara o akutnoj toksičnosti fluorida otkrila je neke manjkavosti u tom znanju (tablica 1.). Imale su problema s odabirom svih simptoma trovanja fluoridima te pravilnih mjera prve pomoći u slučaju akutnog otrovanja. Samo pola ispitanica znalo je kolike su vjerojatne toksične doze, a gotovo petina nije znala koncentraciju fluora u gelu kojim su se djeca koristila. Prosječan broj bodova bio je 6,29 $\pm 2,6$. Statistička analiza pokazala je da su sestre sa završenom srednjom školom imale znatno nižu razinu znanja $(5,9 \pm 2,55)$ od sestara koje su završile viši stupanj obrazovanja - bakala- 
Table 1 Percentage of nurses who correctly answered to questions about fluoride toxicity.

Tablica 1. Postotak sestara koje su točno odgovorile na pitanja o toksičnosti fluorida

\section{Question・Pitanje}

N (134)

$\%$

Do you know the level of fluoride in drinking water in your area? • Znate li kolika je razina fluora u vodi za piće u vašoj okolici?

yes $\bullet$ da

77

Which are real symptoms of acute fluoride toxicity?* ${ }^{*}$ Koji su pravi simptomi akutnoga trovanja fluorom? nausea, vomiting $\bullet$ mučnina, povraćanje

abdominal pain $\bullet$ bol u trbuhu

excess salivation $\bullet$ hipersalivacija

headache $\bullet$ glavobolja

cardiac arrhythmia $\bullet$ srčana aritmija

tetany $\bullet$ tetanija

\begin{tabular}{|c|c|}
\hline 111 & 82.8 \\
\hline 101 & 75.4 \\
\hline 59 & 44 \\
\hline 40 & 29.9 \\
\hline 58 & 43.3 \\
\hline 36 & 26.9 \\
\hline
\end{tabular}

What is the first aid procedure in acute fluoride toxicity?* $\bullet$ Kako se pruža prva pomoć u slučaju akutnog trovanja fluorom? giving milk $\bullet$ konzumiranjem mlijeka

inducing vomiting $\bullet$ poticanjem povraćanja

quick referral to hospital $\bullet$ brzim prijevozom u bolnicu

What is a PTD in children $\bullet$ Koja je doza vjerojatno toksična za djecu?

$1-5 \mathrm{mg} / \mathrm{kg}$

What is the content of fluorides in gel for topical use? • Koji je udio fluorida u gelu za topikalnu primjenu?

$12,5 \mathrm{mg} / 1 \mathrm{~g}$

$60+44.8$

\begin{tabular}{l|c|}
\hline 47 & 35.1 \\
\hline 75 & 56
\end{tabular}

75

* multiple-response question $\bullet$ pitanja $s$ više odgovora

Table 2 Factors influencing nurses' knowledge.

Tablica 2. Čimbenici koji utječu na znanje sestara

\begin{tabular}{|c|c|c|}
\hline & $\begin{array}{c}\text { No. of points } \\
\text { Broj bodova }(\mathrm{SD})\end{array}$ & $\mathbf{p}^{*}$ \\
\hline \multicolumn{2}{|l|}{ Education • Školovanje: } & \multirow{4}{*}{0.019} \\
\hline secondary • srednja škola & $5.9(2.55)$ & \\
\hline Bachelor's degree $\bullet$ bakalaureat & $7.29(3.0)$ & \\
\hline Master's degree $\bullet$ magisterij & $7.6(2.16)$ & \\
\hline \multicolumn{2}{|l|}{ Location of school • Lokacija škole: } & \multirow{5}{*}{0.063} \\
\hline city $\bullet \operatorname{grad}$ & $5.3(2.59)$ & \\
\hline town up to $100000 \cdot \operatorname{grad}$ do 100000 & $6.39(2.77)$ & \\
\hline town up to $20000 \bullet \operatorname{grad}$ do 20000 & $6.68(2.54)$ & \\
\hline village $\bullet$ selo & $7.36(2.02)$ & \\
\hline \multicolumn{2}{|l|}{ Training on caries prevention $\bullet$ Izobrazba o prevenciji karijesa: } & \multirow{4}{*}{0.984} \\
\hline yes $\bullet$ da & $6.19(2.04)$ & \\
\hline no $\bullet$ ne & $6.43(2.63)$ & \\
\hline don't remember $\bullet$ ne sjećam se & $5.5(0.7)$ & \\
\hline \multicolumn{2}{|c|}{ Opinion about the effectiveness of topical fluoride treatment $\bullet$ Mišljenje o učinkovitosti topikalne primjene fluorida: } & \multirow{5}{*}{0.879} \\
\hline very efficient $\bullet$ vrlo učinkovito & $6.31(2.76)$ & \\
\hline sufficient $\bullet$ zadovoljava & $6.32(2.33)$ & \\
\hline without any influence $\bullet$ bez utjecaja & $5.57(2.22)$ & \\
\hline no opinion $\bullet$ nemam mišljenje & $6.38(3.71)$ & \\
\hline \multicolumn{2}{|l|}{ Opinion about safety of topical fluoride treatment $\bullet$ Mišljenje o sigurnosti topikalne primjene fluorida: } & \multirow{5}{*}{$<0.000$} \\
\hline totally safe $\bullet$ potpuno sigurno & $4.47(2.02)$ & \\
\hline safe subject to proper procedures $\bullet$ sigurno, ali ako se pravilno provodi & $6.85(2.54)$ & \\
\hline doubts about safety $\bullet$ sumnja u sigurnost & $5.83(3.12)$ & \\
\hline great risk of overexposure to fluorides $\bullet$ veliki rizik u slučaju prevelike izloženosti fluoridima & $6.0(3.46)$ & \\
\hline
\end{tabular}

points obtained by the nurses was $6.29 \pm 2.6$. The statistical analysis showed that the nurses with secondary education had a significantly lower level of knowledge $(5.9 \pm 2.55)$ than the respondents with higher education, respectively Bachelor's and Master's degree, $7.29 \pm 3$ and $7.6 \pm 2.16(\mathrm{p}=0.019$, the ureat i magisterij $(7,29 \pm 3$ te 7,6 $\pm 2,16(\mathrm{p}=0,019-\mathrm{Kru}$ skal-Wallisov test). Nije bilo razlika u razini znanja ovisno o mjestu škole i sudjelovanju u izobrazbi o prevenciji karijesa (tablica 2.). No, znanje je bilo povezano s mišljenjem o učinkovitosti i sigurnosti terapije fluoridima. Sestre koje nisu bile 
Kruskal-Wallis test). There were no differences in the level of knowledge depending on location of school and participation in training on caries prevention (Tab. 2). However, the knowledge was associated with nurses' opinions about the effectiveness and safety of fluoride treatment. Nurses who were not aware of a potential harmful effect of fluoride and those with a negative opinion about the effectiveness of the fluoride program at school had a statistically significantly lower level of knowledge (Table 2).

\section{Discussion}

Apart from home, healthy behaviors should also be introduced and developed at school. A motivating influence of school with regard to oral health also reaches, through children, the families and local communities. School nurses may be promoters of oral health behaviors and providers of caries prophylaxis (16). Almost all investigated nurses included oral health topics in their duties. They discussed the role of hygiene and diet in caries development, instructed pupils how to brush teeth and provided the fluoride topical treatment. Moreover, almost a half of the respondents declared that caries prevention took a substantial part of their work time with pupils. Also children, especially from rural locations, felt that the school nurse was the appropriate person to ask for an oral health consultation.

The school-based oral hygiene programs may be effective in improving oral health $(17,18)$. Extensive evidence points to a high effectiveness in dental caries prevention by a regular use of fluoride preparations in the school environment, which was confirmed by the opinion of evaluated nurses. The advantages of such prevention include primarily an easy accessibility to the children and the possibility to regularly perform the procedures. The Polish school-based fluoride program is addressed to all children attending primary schools. However, the latest research by the Mother and Child Institute (19) revealed that a large group of school nurses (above 1/3) had difficulties in performing the fluoridation in pupils. Nurses most frequently report the reluctance of pupils to take part in the procedures (68.8\%), difficulties in obtaining toothbrushes $(52.9 \%)$, difficulties related to excusing pupils from class for the time of fluoridation (29.4\%), difficulties resulting from the lack of place for the storage of toothbrushes (17\%) (19). In our study, the mean percentage of pupils taking part in the program constituting more than $90 \%$ of the school population was significant. However, in several cases the nurses declared that less than a half of the pupils took part in the fluoridation. The refusal of parents to give consent to the participation of their child in caries preventions procedures at school may be due to numerous reasons: the lack of indication for fluoridation in individuals with a low risk of caries, the lack of parents' awareness of advantages of this procedure, the lack of trust in public healthcare as well as the avoidance of preparations containing fluoride. According to the study of Hendaus et al. (20), many parents are not sure of the safety of fluoride preparations used in children. Therefore, it is important that the nurses are convinced of the safety of using fluoride prevention and are able to give svjesne potencijalno štetnog djelovanja fluorida i one koje su imale negativno stajalište o učinkovitosti programa fluoridacije u školama, imale su statistički značajno nižu razinu znanja (tablica 2.).

\section{Rasprava}

Zdrav način života trebao bi se uvesti i promicati kod kuće i u školama. Motivirajući utjecaj škole, kad je riječ o oralnome zdravlju, obuhvaća, zahvaljujući djeci, i obitelji i lokalnu zajednicu. Školske medicinske sestre mogu biti promotorice oralnoga zdravlja i pružateljice mjera za zaštitu od karijesa (16). Gotovo sve sestre koje su sudjelovale u istraživanju uvrstile su u svoje dužnosti i teme o oralnome zdravlju. Razgovaraju s učenicima o ulozi higijene i prehrane u razvoju karijesa, pokazuju im kako četkati zube te topikalno primjenjuju fluorid. Nadalje, gotovo polovina anketiranih izjavila je da je prevencija karijesa važan dio njihova rada s učenicima. Djeca, posebno u seoskim područjima, imaju osjećaj da je školska medicinska sestra prava osoba za razgovor i konzultaciju o oralnoj higijeni.

Programi oralne higijene koji se provode u školama učinkovito poboljšavaju oralnu higijenu $(17,18)$. Mnogobrojni su dokazi koji pokazuju da je redovito korištenje preparata fluora visoko učinkovito u prevenciji karijesa, a to mišljenje potvrdile su i medicinske sestre. Prednosti toga načina prevencije su dostupnost djece i mogućnost redovite provedbe procedure. Poljski programi fluoridacije za škole uključuju svu djecu koja pohađaju osnovnu školu, no novije istraživanje Instituta za majku i dijete (19) pokazalo je da velika skupina (više od 1/3) školskih medicinskih sestara ima poteškoće u provedbi toga postupka. Sestre najčešće navode nevoljkost djece da sudjeluju u postupcima $(68,8 \%)$, probleme zbog odlaska djece s nastave kako bi se obavila fluoridacija $(29,4 \%)$ te poteškoće u vezi s nedostatkom mjesta za skladištenje četkica za zube (17\%). U našem istraživanju je prosječan postotak djece koja sudjeluju u programu iznosio više od $90 \%$ školske populacije te je bio znatan. No, u nekoliko slučajeva sestre su izjavile da je manje od pola učenika sudjelovalo u fluoridaciji. Razlozi za to su višestruki - nedostatak indikacije za fluoridaciju kod pojedinaca s niskim rizikom od karijesa, premala svijest roditelja o prednostima tog postupka, premalo povjerenja u javni zdravstveni sustav te izbjegavanje preparata koji sadržavaju fluor. Prema istraživanju Hendausa i suradnika (20), velik broj roditelja ne vjeruje u sigurnost preparata fluora za djecu. Zato je važno da su sestre uvjerene u sigurnost upotrebe fluorida u prevenciji te da mogu dati objašnjenja roditeljima koji su zabrinuti zbog tih postupaka. Posebno je to važno zbog mnogobrojnih pokreta protiv upotrebe fluorida (21). U našem istraživanju manje je od $6 \%$ sestara sumnjalo u sigurnost visokih koncentracija fluora. Većina je vjerovala da pravilna procedura jamči sigurnost. 
explanations to parents being anxious about such procedures. It is particularly important in the context of numerous movements against the use of fluoride (21). In our study, less than $6 \%$ of nurses themselves had doubts about the safety of high concentration of fluorides. The majority of nurses correctly believed that the proper procedure guaranteed its safety.

In fact, the risk of hazardous effects of fluoride ingestion is very low in school-based programs, but the staff responsible for the application of gels or varnishes should be familiar with the symptoms of acute toxicity. We revealed the gap existing in this area. Many respondents did not know the level of fluoride in drinking water despite the fact that it is an important aspect of indications for the topical application of fluorides. In areas where the optimal level of fluoride in drinking water (0.8-1.2 ppm) is exceeded, there is no indication to apply fluorides topically. An acute fluoride poisoning has many symptoms, but evaluated nurses were not able to identify all of them. Moreover, less than a half of the respondents knew that the administration of milk is the first aid for a victim.

It has to be stressed that such gaps in knowledge could be expected. Golinveaux et al. (22) found that pediatric nurses were not able to correctly answer the questions related to the hazardous effect of fluoride ingestion. The lack of knowledge of fluorides was also found in dental staff, even in dentists $(23,24)$. It is obvious that nurses need to acquire knowledge to become competent and skilled to take action against caries. A study on pediatric nurses showed that gaps were improved by the interdisciplinary, multifaceted education (22). We found that the level of knowledge was dependent on education, to the disadvantage of respondents who did not have a university diploma. Unfortunately, most Polish school nurses have only secondary education. The lack of knowledge corresponded with the conviction of complete safety of fluorides in children, which may result in less supervision of the children during the procedure.

Our study revealed that the cooperation between school nurses and local dentists was insufficient and there was no obligatory training for them with regard to the application of topical fluorides and other aspects of caries prevention. It seems that it is time to call for action to prepare an educational program for school nurses to help them with their role as oral health promoters. New media such as the Internet can be used for the communication with nurses to save their time and effort.

\section{Conclusion}

Polish school nurses have the ability to incorporate oral health at the school setting. They have positive attitudes toward topical fluoride treatment in pupils. The gaps in their knowledge should be filled by increasing the education level and developing institutional training.

\section{Acknowledgments}

Authors would like to express their gratitude to all participants for their time and effort during filling in the question-
Zapravo je rizik od nepovoljnog djelovanja progutanog fluora veoma nizak kad je riječ o programima koji se provode u školama, ali osoblje odgovorno za primjenu gelova ili lakova mora poznavati simptome akutnog otrovanja. Otkrili smo nedostatak u tom području. Mnoge ispitanice nisu znale kolika je razina fluora u vodi za piće, unatoč činjenici da je to bitan aspekt indikacije za topikalnu primjenu fluorida. U područjima gdje je optimalna razina fluora u vodi za piće $(0,8-1,2 \mathrm{ppm})$ prekoračena, nema indikacije za topikalnu primjenu fluorida. Akutno otrovanje fluorom ima mnoge simptome, ali educirane medicinske sestre nisu bile u stanju identificirati sve. Štoviše, manje od pola njih znalo je da je konzumacija mlijeka prva pomoć uz slučaju otrovanja.

Potrebno je istaknuti da su nedostatci u znanju očekivani. Golinveaux i suradnici (22) ustanovili su da sestre na pedijatriji ne znaju točno odgovoriti na pitanja o štetnom djelovanju progutanog preparata fluora. Premalo znanja o fluoridima ustanovljeno je i kod dentalnog osoblja, pa čak i kod doktora dentalne medicine $(23,24)$. Očito je da sestre moraju usvojiti nova znanja kako bi bile kompetentne i spremne odgovarajuće djelovati u prevenciji karijesa. Istraživanje u kojemu su sudjelovale sestre na pedijatriji otkrilo je nedostatke koji su nadoknađeni interdisciplinarnom, višeslojnom izobrazbom (22). Mi smo ustanovili da je razina znanja ovisila o izobrazbi, na štetu onih ispitanica koje nisu imale sveučilišnu diplomu. Nažalost, većina poljskih školskih medicinskih sestara nema tu razinu obrazovanja. Nedostatak znanja odgovarao je uvjerenju o potpunoj sigurnosti fluorida koji se primjenjuju, što može rezultirati manjom kontrolom tijekom postupka.

U našem istraživanju istaknuto je da suradnja između školskih medicinskih sestara i lokalnih doktora dentalne medicine nije dovoljna, te da nema obvezne izobrazbe sestara o topikalnoj primjeni fluorida i o drugim aspektima prevencije karijesa. Cini se da je trenutak da se pripremi edukacijski program za školske sestre koji će im pomoći u ulozi promotorica oralnoga zdravlja. Novi mediji, ponajprije internet, mogu se iskoristiti za kontakt sa sestrama, čime bi se uštedjelo njihovo vrijeme, ali i smanjio napor.

\section{Zaključak}

Školske medicinske sestre u Poljskoj znaju primijeniti mjere za oralno zdravlje u školskom okružju. Imaju pozitivna stajališta o topikalnoj primjeni fluorida kad je riječ o učenicima. Nedostatci u njihovu znanju trebali bi se popraviti povećavanom razinom izobrazbe i razvijanjem institucionalizirane edukacije.

\section{Zahvale}

Autori zahvaljuju svim ispitanicama na vremenu i trudu tijekom ispunjavanja upitnika te studentima iz Studentskoga 
naire and to the students from the Student Research Club 'StuDentio' at the Department of Dentistry Propaedeutics, Medical University of Bialystok, for their assistance in data collection.

\section{Conflict of interest}

The authors report no conflict of interest istraživačkog kluba StuDentio pri Zavodu za dentalnu propedeutiku Medicinskog fakulteta u Bialystoku (Poljska) za pomoć u prikupljanju podataka.

\section{Sukob interesa}

Autori nisu bili u sukobu interesa.

\section{Sažetak}

Cilj: Željelo se procijeniti mišljenje školskih medicinskih sestara u Poljskoj o topikalnoj primjeni fluorida te njihovo znanje o sigurnosti toga kemijskog spoja. Metoda: U presječnom istraživanju s pomoću anketnog upitnika sudjelovale su 164 školske medicinske sestre. Anketa je obuhvaćala raniju izobrazbu o prevenciji karijesa, mjere poduzete u školama kako bi se prevenirao karijes, suradnju s doktorima dentalne medicine, mišljenje o topikalnoj primjeni fluorida te znanja sestara o njihovoj sigurnosti. Rezultati: Oralno zdravlje bilo je uvršteno u dužnost $93,9 \%$ sestara, a $81,7 \%$ provodilo je lokalnu primjenu fluorida. U izobrazbi o oralnoj problematici nikada nije sudjelovalo njih $52,1 \%$. Sestre iz gradova češće su sudjelovale i održavale predavanja o prevenciji karijesa i o fluoridima od svojih kolegica u manjim gradovima ( $p=0,033$ i 0,021 - hi-kvadrat test). Sestre su imale pozitivno stajalište o učinkovitosti i sigurnosti topikalne primjene fluorida. Samo je polovina ispitanica znala za moguću toksičnu dozu, a jedna petina nije znala kolika je koncentracija fluora u gelu. Ta su znanja bila statistički važna, ovisno o razini izobrazbe pojedine sestre ( $p=0,019$ - Kruskal-Wallisov test). One s niskom razinom znanja nisu bile svjesne moguće štetnosti fluorida te su imale negativno stajalište o učinkovitosti programa fluoridacije u školama. Zaključak: Školske medicinske sestre u Poljskoj imale su pozitivno mišljenje o topikalnoj primjeni fluorida. No, ima manjkavosti u njihovu znanju pa im je potrebna institucionalizirana izobrazba.
Zaprimljen: 6. siječnja 2019. Prihvaćen: 24. travnja 2019.

Adresa za dopisivanje Joanna Baginska Medical University of Bialystok Department of Dentistry Propaedeutics Ul. Szpitalna 30, 15-295 Bialystok Poland jbaginska@wp.pl

Ključne riječ školske medicinske sestre, topikalna primjena fluorida, znanja

\section{References}

1. Kassebaum NJ, Bernabé E, Dahiya M, Bhandari B, Murray CJ, Marcenes W. Global burden of untreated caries: a systematic review and metaregression. J Dent Res. 015 May;94(5):650-8.

2. Polish Ministry of Health [database on the Internet]. Monitorowanie stanu zdrowia jamy ustnej populacji polskiej w latach 2016--2020. Available from http://www.mz.gov.pl/wp-content/ uploads/2013/12/monitoring-2016-2020.doc.

3. List S, Galloway J, Mossey PA, Marcenes W. Global Economic Impact of Dental Diseases. J Dent Res. 2015 Oct;94(10):1355-61.

4. Pulache J, Abanto J, Oliveira LB, Bönecker M, Porras JC. Exploring the association between oral health problems and oral health-related quality of life in Peruvian 11- to 14-year-old children. Int J Paediatr Dent. 2016;26(2):81-90.

5. Buzalaf MA, Pessan JP, Honório HM, ten Cate JM. Mechanisms of action of fluoride for caries :control. Monogr Oral Sci. 2011;22:97114.

6. Kanduti D, Sterbenk P, Artnik B. Fluoride: a review of use and effects on health. 2016 Apr;28(2):133-7.

7. Weynat RJ, Tracy SL, Anselmo T, Beltrán-Aguilar ED, Donly KJ, Frese WA et al. Topical fluoride for caries prevention. Executive summary of the updated clinical recommendations and supporting systematic review. J Am Dent Assoc. 2013 Nov;144(11):127991.

8. Ogaard B. The cariostatic mechanism of fluoride. Comp Cont Educ Dent. 1999;20(1 Suppl):10-17.

9. DenBesten P, Li W. Chronic fluoride toxicity: dental fluorosis. Monogr Oral Sci. 2011;22:81-96.

10. Clark MB, Slayton RL. Fluoride Use in Caries Prevention in the Primary Care Setting. Pediatrics. 2014;134(3):626-633.

11. Whitford GM. Acute toxicity of ingested fluoride. Monogr Oral Sci. 2011;22:66-80.

12. Marinho VCC, Worthington HV, Walsh T, Chong LY. Fluoride gels for preventing dental caries in and adolescents. Cochrane Database Syst Rev. 2015 Jun 15;(6):CD002280.

13. Andruskeviciene V, Milciuviene S, Bendoraitiene E, Saldunaite K, Vasiliauskiene I, Slabsinskiene E, Narbutaite J. Oral health status and effectiveness of caries prevention programme in kindergartens in Kaunas city (Lithuania). Oral Health Prev Dent. 2008;6(4):343-8.

14. Bergström EK Lingström P, Hakeberg M, Gahnberg L, Sköld UM. Caries and costs: an evaluation of a school-based fluoride varnish programme for adolescents in a Swedish region. Community Dent Health. 2016 Jun;33(2):138-44.

15. Hedman E, Gabre P, Birkhed D. Dental hygienists working in schools - a two-year oral health intervention programme in Swedish secondary schools. Oral Health Prev Dent. 2015;13(2):17788.

16. Buerlein J. Promoting children's oral health. A role for school nurses in prevention, education, and coordination. NASN Sch Nurse. 2010 Jan;25(1):26-9.

17. Melvin CS. A collaborative community-based oral care program for school-age children. Clin Nurse Spec. 2006 Jan-Feb;20(1):18-22.

18. Lai H, Fann IC, Yen AM, Chen LS, Lai MH, Chiu SY. Long-term effectiveness of school-based children oral hygiene program on oral health after 10-year follow-up. Community Dent Oral Epidemiol. 2016;44(3):209-15.

19. Oblacińska A, Jodkowska M, Ostręga W, Radiulkiewicz K, Stalmach M, Tabak I. Nowe problemy i wyzwania w profilaktycznej opiece zdrowotnej nad uczniami w szkole. Raport z badań ankietowych wśród pielęgniarek środowiska nauczania i wychowania w Polsce. [Monograph on the Internet]. Warszawa Instytut Matki i Dziecka. 2017. [cited 2017 Sept 30] Available from: http:// www.moipip.org.pl/media/doc/aktualnosci/2017-03-08__raport_nowe_problemy_i_wyzwania_w_profilaktycznej_opiece_ zdrowotnej nad uczniami w szkole.pdf.

20. Hendaus MA, Jama HA, Siddiqui FJ, Elsiddig SA, Alhammadi AH. Parental preference for fluoride varnish: a new concept in a rapidly developing nation. Patient Prefer Adherence. 2016 Jul 13:10:1227-33.

21. Ota J, Yamamoto T, Ando Y, Aida J, Hirata Y, Arai S. Dental health behaviour of parents of children using non-fluoride toothpaste: $\mathrm{a}$ cross-sectional study. BMC Oral Health. 2013 Dec 29;13:74.

22. Golinveaux J, Gerbert B, Cheng J, Duderstadt K, Alkon A, Mullen S et al. Oral Health Education for Pediatric Nurse Practitioner Students. J Dent Educ. 2018 Jun;82(6):581-590.

23. Bansal R, Bolin KA, Abdellatif HM, Shulma JD. Knowledge, attitude and use of fluorides among dentists in Texas. J Contemp Dent Pract. 2012 May 1;13(3):371-5.

24. Sharma A, Chopra R, Sachdeva S, Sachdev V. Knowledge attitude and practice of Indian dentists on topical application in children. J Dent Specialities. 2017;5(1):36-39. 